\title{
Bilateral Internal Carotid Artery Dissection in Cystathionine Beta-Synthase Deficiency
}

\author{
N. Weiss ${ }^{a} \quad$ S. Demeret $^{a} \quad$ R. Sonneville ${ }^{a} \quad$ R. Guillevin ${ }^{b} \quad$ F. Bolgert ${ }^{a} \quad$ C. Pierrot-Deseilligny ${ }^{a}$ \\ ${ }^{a}$ Réanimation Neurologique, Service de Neurologie 1, and ${ }^{b}$ Département de Neuroradiologie, \\ Hôpital Pitié-Salpêtrière, Paris, France
}

\section{Dear Sir,}

Homocystinuria is the second most common congenital aminoacidopathy after phenylcetonuria [1-3]. The most commonly involved enzyme is cystathionine beta-synthase (CBS) (MIM 236200), responsible for major hyperhomocysteinemia and homocystinuria. Commonly diagnosed during childhood, it is rarely revealed in adult life. Here we report a patient who presented strokes due to bilateral internal carotid occlusion. Etiological workup found CBS deficiency. The mechanism of occlusion was bilateral artery dissection. Only one case of cervical artery dissection in major homocysteinemia has been reported previously [4]. However, increased homocysteine levels were recently described $[5,6]$ in spontaneous cervical artery dissection in young adults.

\section{Case Report}

A 35-year-old white woman was admitted with headache, right arm weakness and painful neck that had commenced 3 days previously. She had a medical history of bilateral luxation of the lenses at the age of 30 , gravidic hypertension, miscarriage and mild depression. Her only vascular risk factor was estroprogestative pill intake. Family medical history was unrevealing. Dihydroergotamine had been given for hypotension 4 days before the first symptoms. On admission to the neurological ward, she was conscious with a headache and right hemiparesis but no neck stiffness. General examination revealed marfanoid features with thin blond hair, arm span:height ratio
$>1.05$ and arched palate. Neither skin abnormalities nor hyperextensible joints were found. She was treated with aspirin at $250 \mathrm{mg}$ daily. Three days later, she suddenly became comatose and was transferred to the neurological intensive care unit for respiratory assistance. Her Glasgow Coma Scale rated 6, she presented with spastic tetraparesis. Cerebral CT scan, Doppler sonography and cerebral MRI suggested ischemic stroke by occlusion of both internal carotid arteries (ICA). On MRA, the left ICA was missing and the right ICA had tapering narrowing aspect. Axial CT angiography confirmed the dissection of both ICAs with intracranial extension (fig. 1a). Transthoracic echocardiography and 24-hour Holter results were normal. Blood sampling found major hyperhomocysteinemia, with total plasma homocysteine at $158 \mu \mathrm{mol} / \mathrm{l}$ (normal $<15 \mu \mathrm{mol} / \mathrm{l})$. The plasmatic methionine level was in the upper normal range. Urinary amino acids chromatography confirmed homocysteinuria at $160 \mu \mathrm{mol} / \mathrm{l}$ (normal $<10$ ). Folates and vitamin $\mathrm{B}_{12}$ were mildly decreased. Antithrombine III, protein $C$ and protein $S$ were within the normal range. Mutation of factor $\mathrm{V}$ Leiden was not detected. She was heterozygote for the C677T mutation of the methylene tetrahydrofolate reductase (MTHFR), but enzymatic activity of MTHFR was normal. On thoraco-abdominal CT scan neither asymptomatic aorta aneurysms nor enlargement of the proximal aorta arch was found. Dural ectasia at lumbosacral level was ruled out by spine MRI. No sign of osteoporosis was found on bone X-ray. Al-
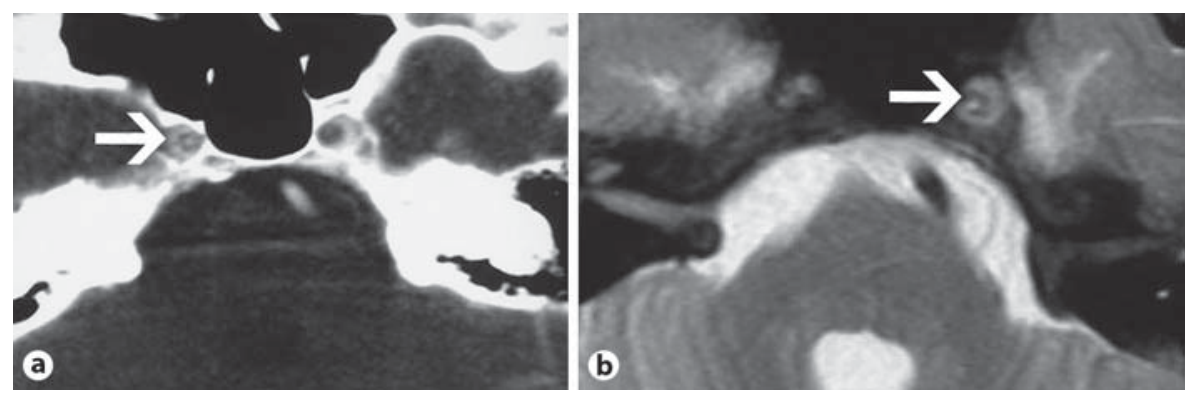

Fig.1. a Axial neck CT angiography showing filling defects with mild dilatation of the left ICA and intimal flap (arrow) of the right ICA with no evidence of atherosclerosis. $\mathbf{b}$ Axial $\mathrm{T}_{2}$ fat saturation MR at 2 months found hyperintensity around signal intensity void (arrow).

\section{KARGER}

Fax +41613061234 E-Mail karger@karger.ch www.karger.com
(C) 2006 S. Karger AG, Basel 0014-3022/06/0553-0177\$23.50/0 www.karger.com/ene
S. Demeret

Service de Neurologie 1, Réanimation Neurologique, Hôpital Pitié-Salpêtrière 47 Boulevard de l'Hôpital

FR-75013 Paris (France)

Tel. +33 14216 2770, Fax +33 14216 1838, E-Mail sophie.demeret@psl.ap-hop-paris.fr 
most no activity of CBS in cultured skin fibroblasts was measurable. Family screening revealed no additional affected member. Without the guidelines of randomized trials but solely on the basis of the clinical time-course and of radiological findings, we considered the ischemic risk to be greater than the bleeding risk, and decided to treat by intravenous heparine therapy. A low methionin diet, with betaine and vitamin supplements (pyridoxine, $\mathrm{B}_{12}$ and folates) was started. After 1 month of appropriate treatment, total plasma homocysteine was down to $61 \mu \mathrm{mol} / \mathrm{l}$, to $51 \mu \mathrm{mol} / \mathrm{l}$ after 2 months and to $13 \mu \mathrm{mol} / \mathrm{l}$ after 1 year. Heparin was switched to aspirin $(250 \mathrm{mg} /$ day $)$ after regularization of homocysteine plasma levels. $\mathrm{T}_{2}$ fat saturation sequence at 2 months is shown in figure $1 \mathrm{~b}$. Neurological improvement slowly ensued, but 1 year after discharge she still presented with right hemiparesis and severe frontal syndrome.

\section{Discussion}

CBS deficiency is the most common cause of major homocysteinemia $[1,2]$. The clinical picture is highly variable, including ectopic lenses, osteoporosis, skeletal abnormalities, marfanoid features, mental retardation, psychiatric disturbances and vascular disease; arterial or venous thromboses are also experienced. Our patient presented with the normal features of the disease at age 30: ectopic lenses, marfanoid features and mild psychiatric disturbance. Dural sac:vertebral body ratio, using MRI, was normal. This ratio is known to identify Marfan syndrome with $95 \%$ sensitivity and $98 \%$ specificity $[7,8]$. Miscarriage has been described previously and related to the disease [9]. Mudd [1] and McCully [10] were the first to describe the relationship between vascular events and CBS deficiency. A common pathogenesis of vascular occlusions in this disease is atherothrombosis. This was confirmed by anatomopathological and sonographic data [11].

Bilateral spontaneous internal carotid dissections are rare events but can occur without any known risk factor (4\% of all internal carotid artery dissections) [12]. Previously, only 1 case of cervical artery dissection was described in CBS deficiency [4].
On the other hand, Konrad et al. [13], comparing spontaneous cervical artery dissection patients with matched healthy individuals, suggested that a moderately elevated homocysteine level is associated with the occurrence of spontaneous cervical artery dissection. Two additional recent studies revealed a link between mild hyperhomocysteinemia and cervical arteries dissection in young adults $[5,6]$. Experimental data suggested activation of elastases and metalloproteases is associated with high levels of homocysteine [14]. Interaction between homocysteine and arterial elastic fibers could play a role in artery dissection [15]. Other connective tissue disorders - i.e. Marfan disease, EhlersDanlos type IV syndrome, osteogenesis imperfecta and pseudoxanthoma elasticum - are known to cause arterial dissections [16].

Our case report supports the hypothesis of a causal relationship between CBS deficiency and ICA dissection. It remains unclear why only 2 cases of artery dissection in CBS deficiency have been described. Other external factors such as drug intake could trigger dissection in previously altered arterial walls.

\section{References}

1 Mudd SH, Skovby F, Levy HL, Pettigrew KD, Wilcken B, Pyeritz RE, Andria G, Boers GH, Bromberg IL, Cerone R, et al: The natural history of homocystinuria due to cystathionine beta-synthase deficiency. Am J Hum Genet 1985;37:1-31.

2 Quere I, Simorre B, Ruivard M, Le Hello C, Parrot F, Megnien JL, Touati G, Chasse JF, Saudubray JM, Zittoun J: Homocystinuria in adulthood (in French). Rev Med Interne 2001; 22(suppl 3):347s-355s.

3 Scriver CR, Beaudet AR, Sly W, Valle D (eds): The Metabolic and Molecular Bases of Inherited Disease, ed 8. New York, McGraw-Hill, vol 1, 2001.

4 Kelly PJ, Furie KL, Kistler JP, Barron M, Picard EH, Mandell R, Shih VE: Stroke in young patients with hyperhomocysteinemia due to cystathionine beta-synthase deficiency. Neurology 2003;60:275-279.

5 Gallai V, Caso V, Paciaroni M, Cardaioli G, Arning E, Bottiglieri T, Parnetti L: Mild hyperhomocysteinemia: a possible risk factor for cervical artery dissection. Stroke 2001;32: 714-748.
6 Pezzini A, Del Zotto E, Archetti S, Negrini R, Bani P, Albertini A, Grassi M, Assanelli D, Gasparotti R, Vignolo LA, Magoni M, Padovani A: Plasma homocysteine concentration, C677T MTHFR genotype, and 844ins68bp CBS genotype in young adults with spontaneous cervical artery dissection and atherothrombotic stroke. Stroke 2002;33:664-669.

7 Nollen GJ, Mulder BJ: What is new in the Marfan syndrome? Int J Cardiol 2004;97(suppl 1):103-108.

8 Oosterhof T, Groenink M, Hulsmans FJ, Mulder BJ, van der Wall EE, Smit R, Hennekam RC: Quantitative assessment of dural ectasia as a marker for Marfan syndrome. Radiology 2001;220:514-518.

9 Barro C, Ducros V, Bonaz B, Muet F, Quenard N, Fontaine M, Polack B, Pernod G: Homocysteinemia and recurrent fetal losses: description of three cases (in French). Ann Biol Clin (Paris) 2002;60:325-326.

10 McCully KS: Vascular pathology of homocysteinemia: implications for the pathogenesis of arteriosclerosis. Am J Pathol 1969;56:111128.

11 Megnien JL, Gariepy J, Saudubray JM, Nuoffer JM, Denarie N, Levenson J, Simon A: Evidence of carotid artery wall hypertrophy in homozygous homocystinuria. Circulation 1998;98:2276-2281.

12 Dziewas R, Konrad C, Drager B, Evers S, Besselmann M, Ludemann P, Kuhlenbaumer G, Stogbauer F, Ringelstein EB: Cervical artery dissection-clinical features, risk factors, therapy and outcome in 126 patients. J Neurol 2003;250:1179-1184.

13 Konrad C, Muller GA, Langer C, Kuhlenbaumer G, Berger K, Nabavi DG, Dziewas R, Stogbauer F, Ringelstein EB, Junker R: Plasma homocysteine, MTHFR C677T, CBS 844ins68bp, and MTHFD1 G1958A polymorphisms in spontaneous cervical artery dissections. J Neurol 2004;251:1242-1248.

14 Charpiot P, Bescond A, Augier T, Chareyre C, Fraterno M, Rolland PH, Garcon D: Hyperhomocysteinemia induces elastolysis in minipig arteries: structural consequences, arterial site specificity and effect of captoprilhydrochlorothiazide. Matrix Biol 1998;17: 559-574.

15 Takagi H, Umemoto T: Homocysteinemia is a risk factor for aortic dissection. Med Hypotheses 2005;64:1007-1010.

16 Schievink WI, VV Michels, Piepgras DG: Neurovascular manifestations of heritable connective tissue disorders. A review. Stroke 1994;25:889-903.
Weiss/Demeret/Sonneville/Guillevin/ Bolgert/Pierrot-Deseilligny 